Research paper

\title{
Fluorescent chemosensor for Al(III) based on chelation-induced fluorescence enhancement and its application in live cells imaging
}

\section{A R T I C L E I N F O}

\section{Keywords:}

Fluorescent sensor

Al(III)

CHEF

Live cells imaging

\begin{abstract}
A B S T R A C T
A tridentate Schiff base receptor BPB was synthesized by condensation of 2-(benzo[b]thiophen-2-yl)benzenamine with salicylaldehyde in ethanolic medium and characterized by various spectral (FT-IR, ${ }^{1} \mathrm{H} \mathrm{NMR},{ }^{13} \mathrm{C}$ NMR and mass) data. The methanolic solution of BPB was applied for the fluorescent sensing of metal ions dissolved in aqueous medium. The selectivity experiment revealed that the receptor BPB showed significant fluorescence enhancement at $430 \mathrm{~nm}$ in the presence of A(III) due to the chelation-induced fluorescence enhancement (CHEF) mechanism. Receptor BPB formed complex with $\mathrm{Al}(\mathrm{III})$ in 2:1 binding ratio with the estimated binding constant of $\mathrm{K}=3.02 \times 10^{8} \mathrm{M}^{-2}$. Without any interference from other tested metal ions, the receptor BPB can detect the concentration of $\mathrm{Al}(\mathrm{III})$ down to $256 \mathrm{nM}$. The receptor BPB showed good cell permeability and was applied for the qualitative and quantitative detection of intracellular Al(III) in A549 cell line (adenocarcinomic human alveolar basal epithelial cells) by using a confocal imaging technique.
\end{abstract}

\section{Introduction}

Aluminum, one of the most abundant metallic element in the earth's crust has diverse applications in chemical industries, aluminum based pharmaceuticals, food additives, water purification, paper making, cosmetic and aerospace industries etc. [1-6]. Although aluminum offers various applications on the day to day life, but excessive use of aluminum is hazardous to the environment and human life. Aluminum components in the earth's atmosphere constitutes to nearly 8\% [7]. Apart from this, acid rain contributes to the enrichment of $\mathrm{Al}$ (III) ion concentration by leaching from the soil, which may be deleterious to the plant growth and hazardous to the organisms [8]. The excessive accumulation of $\mathrm{Al}(\mathrm{III})$ in brain tissues can cause severe damage to central nervous system and increase the risk of neurological diseases like Alzheimer and Parkinson $[9,10]$. Beside this, toxicity of $\mathrm{Al}(\mathrm{III})$ ions can also cause glucose intolerance, kidney failure, cardiac arrest and osteoporosis [11-13]. Because of the health hazards to human life due to excessive exposure or intake of $\mathrm{Al}(\mathrm{III})$ ions, the World Health
Organization (WHO) has recommended dietary limit of aluminum intake should be controlled up to $7 \mathrm{mgKg}^{-1}$ per week [14], whereas the permissible limit of $\mathrm{Al}(\mathrm{III})$ concentration in drinking water is $7.41 \mu \mathrm{M}$. Therefore, the monitoring of $\mathrm{Al}(\mathrm{III})$ ions concentration is considered to be important owing to its potential impact on the environment and human health.

Analytical approaches like inductively coupled plasma atomic emission spectroscopy (ICP-AES), atomic absorption spectrometry (AAS) and inductively coupled plasma-mass spectroscopy (ICP-MS), voltammetry, ion-selective membrane and liquid chromatography-mass spectrometry techniques etc. are available for the monitoring of $\mathrm{Al}(\mathrm{III})$ ion concentration [15-21]. But all these methods are relatively expensive and suffer from issues like tedious pretreatment procedure, need of skilled person and sophisticated laboratory facilities. In comparison, the methods based on colorimetric and fluorescence approaches are proved to be of much interest to scientist due to its simplicity, cost-effectiveness and high sensitivity for the monitoring of target analyte [22-24]. Therefore, there is expedite growth in the

\footnotetext{
* Corresponding authors.

E-mail address: sks@chem.svnit.ac.in (S.K. Sahoo).
} 


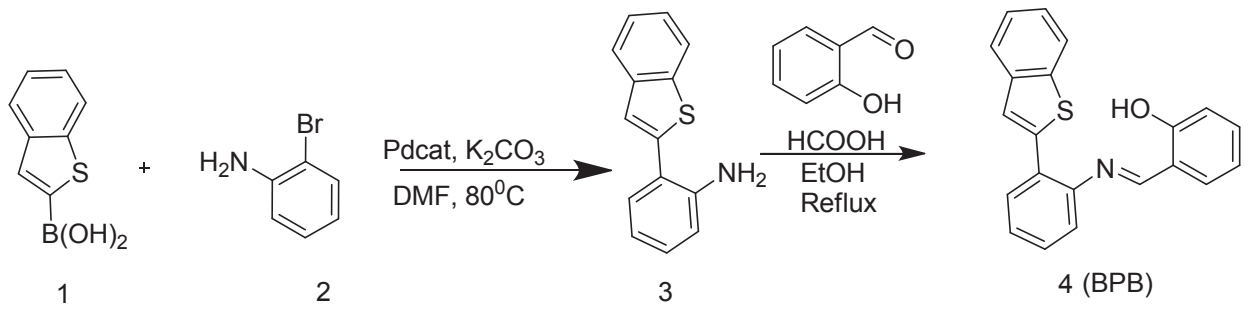

Scheme 1. Synthesis of receptor BPB.

development of optically active chromogenic and fluorogenic chemosensors for the detection of various toxic analytes including $\mathrm{Al}(\mathrm{III})$ ion [25-30]. The Schiff bases with suitable binding sites are extensively investigated for developing chemosensors for metal ions [5,31-44], because of the efficient synthetic approaches and fascinating coordination behavior towards metal ions. Recently, the multidentate Schiff bases with the mechanisms like chelation-enhanced fluorescence (CHEF), aggregation induced emission (AIE), $\mathrm{C}=\mathrm{N}$ isomerization, intramolecular charge transfer (ICT), excited state intramolecular proton transfer (ESIPT), photoinduced charge transfer (PET) and excimer/exciplex formation etc. are commonly employed for the designing of fluorescent sensors for $\mathrm{Al}(\mathrm{III})$ [40-44].

In this manuscript, a new 2-(benzo[b]thiophen-2-yl)benzenamine derived tridentate Schiff base receptor BPB was synthesized (Scheme 1) and applied for the fluorescent sensing of $\mathrm{Al}(\mathrm{III})$ ion. The receptor BPB showed a selective fluorescence enhancement in the presence of A(III) due to the CHEF mechanism, and can be applied for the monitoring of intracellular Al(III) ions concentration in live A549 cells (adenocarcinomic human alveolar basal epithelial cells).

\section{Experimental}

\subsection{Materials and instruments}

All analytical grade reagents used in research were procured from commercial suppliers. Salicylaldehyde, 2-bromoaniline, thiophen-2-ylboronic acid and other chemicals used for the synthesis of BPB were purchased from Sigma-Aldrich. All metal salts used in the sensing experiments were procured from Renkem Pvt. Ltd., India. Thin layer chromatography (TLC) was used as an analysis tool to control and monitor the progress of chemical reaction. The ${ }^{1} \mathrm{H}$ NMR and ${ }^{13} \mathrm{C}$ NMR spectra were recorded in DMSO- $d_{6}$ on a Brukar $400 \mathrm{MHz}$ instrument, where the chemical shifts are given in ppm downfield from TMS as an internal standard. The HRMS and infrared spectra were recorded on a maXis impact and Perkin-Elmer FTIR RX1 spectrometer, respectively. All fluorescence spectra were recorded on an Agilent Technologies (Cary Eclipse Fluorescence Spectrophotometer).

\subsection{Synthesis of $B P B$}

Synthesis of BPB was achieved by the condensation of 2-(benzo[b] thiophen-2-yl) benzenamine (3) with salicylaldehyde in ethanolic medium in the presence of catalytic amount of acid (Scheme 1). The reported intermediate compound 2-(benzo[b]thiophen-2-yl)benzenamine [45] was synthesized by Suzuki coupling between thiophen-2ylboronic acid and 2-bromoaniline in the presence of $\mathrm{PdCl}_{2}\left(\mathrm{PPh}_{3}\right)_{2}$ and potassium carbonate in DMF by following the reported procedure [46].

\subsubsection{Synthesis of 2-(benzo[b]thiophen-2-yl)benzenamine (3)}

The reaction was carried out in a $100 \mathrm{~mL}$ two-necked reaction flask equipped with a reflux condenser, and nitrogen flushing provision. Thiophen-2-ylboronic acid (2.01 g, $11.33 \mathrm{mmol}), \mathrm{PdCl}_{2}\left(\mathrm{PPh}_{3}\right)_{2}$ $(611 \mathrm{mg}, 0.871 \mathrm{mmol})$ and potassium carbonate $(1.245 \mathrm{~g}, 8.71 \mathrm{mmol})$ were placed in reactor assembly, and the flask was flushed with nitrogen. $50 \mathrm{~mL}$ DMF, $9 \mathrm{~mL}$ water and 2-bromoaniline $(1.5 \mathrm{~g}$, $8.7 \mathrm{mmol}$ ) were added, and the resulting solution was stirred at $80{ }^{\circ} \mathrm{C}$ for $24 \mathrm{hr}$. After cooling, the reaction mixture was diluted with ethyl acetate and the aqueous layer was saturated with $\mathrm{NaHCO}_{3}$ and filtered off through a short pad of celite. The filtrate was extracted with ethyl acetate and the combined organic layer was dried over sodium sulfate. The solvent was evaporated using a rotary evaporator followed by silica gel column purification with hexane/ethyl acetate (5:1, v/v) gave 2(benzo[b]thiophen-2-yl)benzenamine $(1.0 \mathrm{~g}, 4.43 \mathrm{mmol})$ in $63.5 \%$ yield.

\subsubsection{Synthesis of $B P B$}

2-(benzo[b]thiophen-2-yl)benzenamine (0.5 g, $2.21 \mathrm{mmol}$ ), salicylaldehyde $(0.271 \mathrm{~g}, 2.21 \mathrm{mmol})$ and catalytic amount of formic acid in $15 \mathrm{~mL}$ ethanol were placed in $100 \mathrm{~mL}$ single necked reaction flask equipped with a reflux condenser, and the resulting solution was stirred at $80{ }^{\circ} \mathrm{C}$ for $16 \mathrm{hrs}$. After completion of the reaction, the excess solvent was removed under reduced pressure. The crude product was washed with $\mathrm{H}_{2} \mathrm{O}$ and dried, gave $\mathrm{BPB}$ as yellow solid $(0.5 \mathrm{~g}, 1.51 \mathrm{mmol})$ in $65 \%$ yield.

FT-IR (KBr discs, cm $^{-1}$ ): 3250, 3057, 2904, 1609, 1587, 1576, 1515, 1493, 1455, 1479, 1395, 1370, 1308, 1274, 1249; ${ }^{1} \mathbf{H}$ NMR (400 MHz, DMSO- $\boldsymbol{d}_{6}, \boldsymbol{\delta} \mathrm{ppm}$ ): $12.20(\mathrm{~s}, 1 \mathrm{H}$ ), $8.94(\mathrm{~s}, 1 \mathrm{H}), 7.96-7.95$ (dd, 1H), 7.85-7.77 (m, 3H), $7.71(\mathrm{~s}, 1 \mathrm{H}), 7.53-7.49(\mathrm{~m}, 1 \mathrm{H})$, 7.44-7.34 (m, 5H), 7.00-6.99 (m, 1H), 6.94-6.93 (m,1H); ${ }^{13} \mathrm{C}$ NMR (100 MHz, DMSO- $d_{6}, \delta$ ppm): 163.63, 159.76, 146.93, 140.11, $140.033,139.45,133.67,132.16,129.82,129.58,127.89,126.92$, $124.57,124.50,123.76,123.44,122.12,120.12,119.98,116.62 ; \mathbf{M} / \mathbf{Z}$ $(\mathbf{M}+\mathbf{H})^{+}$: Expt. 330.06, Calc. 329.09 .

\subsection{Spectroscopic study}

Due to the insolubility of the receptor BPB in water, the stock solution of $\mathrm{BPB}$ was prepared in $\mathrm{CH}_{3} \mathrm{OH}$. All cations $\left(1.0 \times 10^{-3} \mathrm{M}\right)$ solutions were prepared in water. These solutions are used for various spectroscopic studies after appropriate dilution. For the fluorescence titration, the required amount of the diluted receptor BPB $(2 \mathrm{~mL}$, $1 \times 10^{-5} \mathrm{M}$, in $\mathrm{CH}_{3} \mathrm{OH}$ ) was taken directly into the cuvette and the spectra were recorded after each aliquot $(10 \mu \mathrm{L})$ addition of $\mathrm{Al}(\mathrm{III})$ $\left(1 \times 10^{-3} \mathrm{M}, \mathrm{H}_{2} \mathrm{O}\right)$ by using a micropipette. Using the fluorescence titration data, the calibration curve between the emission intensity at $430 \mathrm{~nm}$ was plotted against the added concentration of $\mathrm{Al}(\mathrm{III})$. Using the IUPAC approved equation, the limit of detection (LOD) of the receptor BPB was calculated. The LOD was calculated using the relationship, $\mathrm{LOD}=(3 \times$ standard deviation $) /$ slope of the calibration curve. To calculate the relative standard deviation, the fluorescence spectra of ten blank samples were recorded. Using the fluorescence titration data, the binding constant $(\mathrm{K})$ of the complex formed between $\mathrm{BPB}$ and $\mathrm{Al}(\mathrm{III})$ was determined by applying the Benesi-Hildebrand equation:

$\frac{1}{\mathrm{~F}-\mathrm{F} 0}=\frac{1}{\mathrm{~K}(F \max -F 0)[\mathrm{Al}(\mathrm{III})]^{2}}+\frac{1}{\mathrm{Fmax}-\mathrm{F} 0}$

where $\mathrm{F}$ and F0 are the emission intensity of BPB solution in the 
presence and absence of $\mathrm{Al}(\mathrm{III})$ ions, Fmax is the saturated emission intensity of $\mathrm{BPB}$ in the presence of excess amounts of $\mathrm{Al}(\mathrm{III}),[\mathrm{Al}(\mathrm{III})]$ is the concentration of added $\mathrm{Al}(\mathrm{III})$ ions $\left(\mathrm{mol} \mathrm{L}^{-1}\right)$.

\subsection{Living cells imaging}

The A549 cells were incubated with DMEM supplemented with $10 \%$ (v/v) fetal bovine serum (FBS, Gibco, USA) at $37^{\circ} \mathrm{C}$ under a humidified atmosphere containing $5 \% \mathrm{CO}_{2}$. A549 cells were placed on Petri-dishes $(\Phi=20 \mathrm{~mm})$ and allowed to adhere for $24 \mathrm{hrs}$ before the treatments. The fluorescence images of A549 cells were acquired on a confocal laser scanning microscope (Japan Olympus Co., Ltd) with an objective lens (oil, $\times 60$ ). The excitation wavelength was $405 \mathrm{~nm}$, and the collected wavelength was $410-440 \mathrm{~nm}$. The cell imaging was carried out by adding receptor BPB of $10 \mu \mathrm{M}$ to glass bottom cell culture Petri-dishes.

\section{Results and discussion}

\subsection{Preliminary selectivity study of $B P B$}

The receptor BPB was synthesized by reacting equimolar amount of 2-(benzo $[b]$ thiophen-2-yl)benzenamine with salicylaldehyde in ethanolic medium in the presence of catalytic amount of formic acid. The receptor BPB was characterized by FT-IR, ${ }^{1} \mathrm{H}$ NMR, ${ }^{13} \mathrm{C}$ NMR and HRMS data (Figs. S1-S4). The recognition ability of BPB $\left(2 \mathrm{~mL}, 1 \times 10^{-5} \mathrm{M}\right.$, in $\mathrm{CH}_{3} \mathrm{OH}$ ) was examined by observing naked-eye detectable colour changes under day and UV light after adding different metal ions (100 $\mu \mathrm{L}, 1 \times 10^{-3} \mathrm{M}$, in $\mathrm{H}_{2} \mathrm{O}$ ), such as $\mathrm{Al}(\mathrm{III}), \mathrm{Ag}(\mathrm{I}), \mathrm{Ca}(\mathrm{II}), \mathrm{Cd}(\mathrm{II})$, Co (II), $\mathrm{Cu}(\mathrm{II}), \mathrm{Fe}(\mathrm{II}), \mathrm{Hg}(\mathrm{II}), \mathrm{K}(\mathrm{I}), \mathrm{Li}(\mathrm{I}), \mathrm{Mg}(\mathrm{II}), \mathrm{Mn}(\mathrm{II}), \mathrm{Ni}(\mathrm{II}), \mathrm{Pd}(\mathrm{II})$ and $\mathrm{Zn}$ (II). In the naked-eye experiments, the BPB solutions showed no-obvious visual color changes under day light in the presence of tested metal ions (Fig. S5). However, the receptor BPB illustrated a selective "turn-on" fluorescence response in the presence of $\mathrm{Al}(\mathrm{III})$ ions over other tested metal ions under UV light irradiated at $365 \mathrm{~nm}$ (Fig. 1). The observed distinct fluorescent colour change prompted us to develop the receptor $\mathrm{BPB}$ for the fluorescent sensing of $\mathrm{Al}(\mathrm{III})$.

\subsection{Emission spectroscopic study of BPB}

The metal ions sensing ability of $\mathrm{BPB}$ was investigated by fluorescence spectroscopy. The receptor BPB $\left(2 \mathrm{~mL}, 1 \times 10^{-5} \mathrm{M}\right.$, in $\left.\mathrm{CH}_{3} \mathrm{OH}\right)$ was non-fluorescent, when excited at $320 \mathrm{~nm}$. The non-fluorescent nature of BPB may be due to the conformational flexibility that allows non-radiative decay from the excited state along with the photo-induced electron transfer (PET) [47-49]. When the BPB was interacted with different metal ions $\left(100 \mu \mathrm{L}, 1 \times 10^{-3} \mathrm{M}\right.$, in $\left.\mathrm{H}_{2} \mathrm{O}\right)$, addition of $\mathrm{Al}$ (III) caused a significant fluorescence enhancement at $430 \mathrm{~nm}$ (Fig. 2). The fluorescence enhancement can be explained due to the chelationinduced fluorescence enhancement (CHEF) and the inhibition of PET [47-49]. The selective complexation between BPB and Al(III) restricts the conformational flexibility at the excited state upon inhibition of $\mathrm{C}=$ $\mathrm{N}$ isomerization resulted significant fluorescence enhancement. Other tested metal ions failed to perturb the fluorescence profile of BPB, which supported the high selective towards $\mathrm{Al}(\mathrm{III})$.

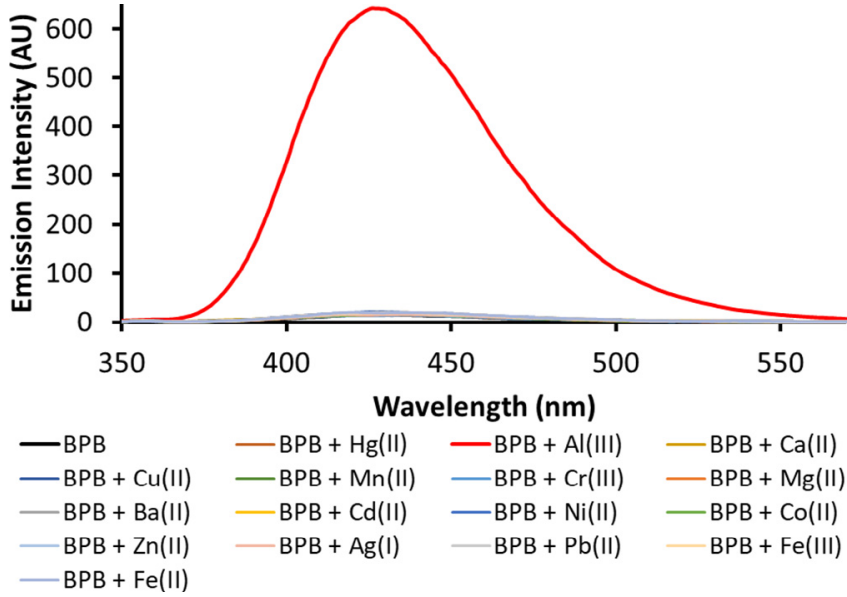

Fig. 2. Fluorescence emission changes of $\mathrm{BPB}\left(2 \mathrm{~mL}, 1 \times 10^{-5} \mathrm{M}, \mathrm{CH}_{3} \mathrm{OH}\right)$ upon the addition of $\sim 5$ equivalents $\left(4.76 \times 10^{-5} \mathrm{M}\right)$ of different metal ions $\left(100 \mu \mathrm{L}, 1 \times 10^{-3} \mathrm{M}\right.$, in $\left.\mathrm{H}_{2} \mathrm{O}\right)$.

The interference of coexisting metal ions on the detection of $\mathrm{Al}(\mathrm{III})$ by $\mathrm{BPB}$ was investigated by performing competitive experiments, where the fluorescence spectra of BPB $\left(2 \mathrm{~mL}, 1 \times 10^{-5} \mathrm{M}\right.$, in $\left.\mathrm{CH}_{3} \mathrm{OH}\right)$ were recorded in the presence of $\mathrm{Al}^{3+}\left(60 \mu \mathrm{L}, 1 \times 10^{-3} \mathrm{M}\right.$, in $\left.\mathrm{H}_{2} \mathrm{O}\right)$ and equimolar amounts of other interfering metal ions $\left(60 \mu \mathrm{L}, 1 \times 10^{-3} \mathrm{M}\right.$, in $\mathrm{H}_{2} \mathrm{O}$ ). The bar representation of change in fluorescence intensity of $\mathrm{BPB}$ at $430 \mathrm{~nm}$ revealed that the detection of $\mathrm{Al}(\mathrm{III})$ is not interfered in the coexistence of tested interfering metal ions (Fig. 3). Therefore, the receptor BPB can be explored for the highly selective fluorescent "turnon" sensing of $\mathrm{Al}(\mathrm{III})$ ions.

The fluorescence titration experiment was carried out to determine the sensitivity of the receptor $\mathrm{BPB}$, where the fluorescence spectra of BPB $\left(2 \mathrm{~mL}, 1 \times 10^{-5} \mathrm{M}\right.$, in $\left.\mathrm{CH}_{3} \mathrm{OH}\right)$ were recorded after each aliquot $(10 \mu \mathrm{L})$ addition of $\mathrm{Al}(\mathrm{III})\left(0-100 \mu \mathrm{L}, 1 \times 10^{-3}\right.$, in $\left.\mathrm{H}_{2} \mathrm{O}\right)$. The fluorescence intensity of BPB was increased at $430 \mathrm{~nm}$ with the successive incremental addition of $\mathrm{Al}(\mathrm{III})$ (Fig. 4). The increase in fluorescence intensity at $430 \mathrm{~nm}$ of BPB was plotted against the added concentration of $\mathrm{Al}(\mathrm{III})$. From the calibration curve (Fig. S6), the LOD of receptor BPB was estimated as $256 \mathrm{nM} \mathrm{Al(III).} \mathrm{The} \mathrm{estimated} \mathrm{LOD} \mathrm{is} \mathrm{far} \mathrm{better} \mathrm{than}$ the permissible limit of $\mathrm{Al}(\mathrm{III})$ concentration in drinking water. Also, the LOD is comparable/superior than the recently reported Al(III) fluorescent sensors summarized in Table S1.

The fluorescence spectral changes of BPB clearly supported the formation of new species in solution after interaction with $\mathrm{Al}(\mathrm{III})$. To investigate the binding stoichiometry of new species formed between $\mathrm{BPB}$ and $\mathrm{Al}(\mathrm{III})$ in solution, the job's plot analysis was carried out that showed the fluorescence maxima at the mole fraction of 0.3 . The job's plot analysis indicates the formation of a host-guest BPB-Al(III) complex in 2:1 binding stoichiometry (Fig. 5). Analyzing fluorescence titration data with Benesi-Hildebrand equation, the binding constant $(\mathrm{K})$ of $3.02 \times 10^{8} \mathrm{M}^{-2}$ was estimated for the BPB-Al(III) complex species formed in solution (Fig. S7). The obtained binding constant revealed the high affinity of the receptor BPB to form complex with $\mathrm{Al}(\mathrm{III})$,

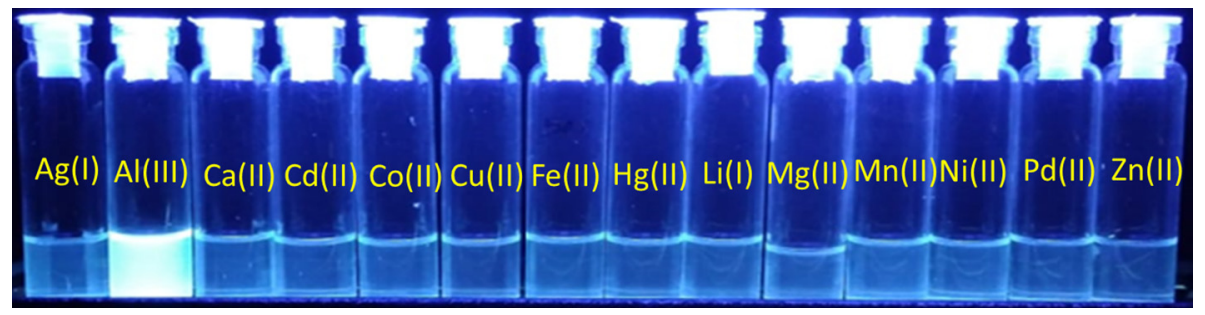

Fig 1. Vials irradiated with UV light at $365 \mathrm{~nm}$ containing BPB $\left(2 \mathrm{~mL}, 1 \times 10^{-5} \mathrm{M}\right.$, in $\left.\mathrm{CH}_{3} \mathrm{OH}\right)$ in presence of $\sim 5$ equivalents $\left(4.76 \times 10^{-5} \mathrm{M}\right)$ of different tested metal ions $\left(100 \mu \mathrm{L}, 1 \times 10^{-3} \mathrm{M}\right.$, in $\left.\mathrm{H}_{2} \mathrm{O}\right)$. 


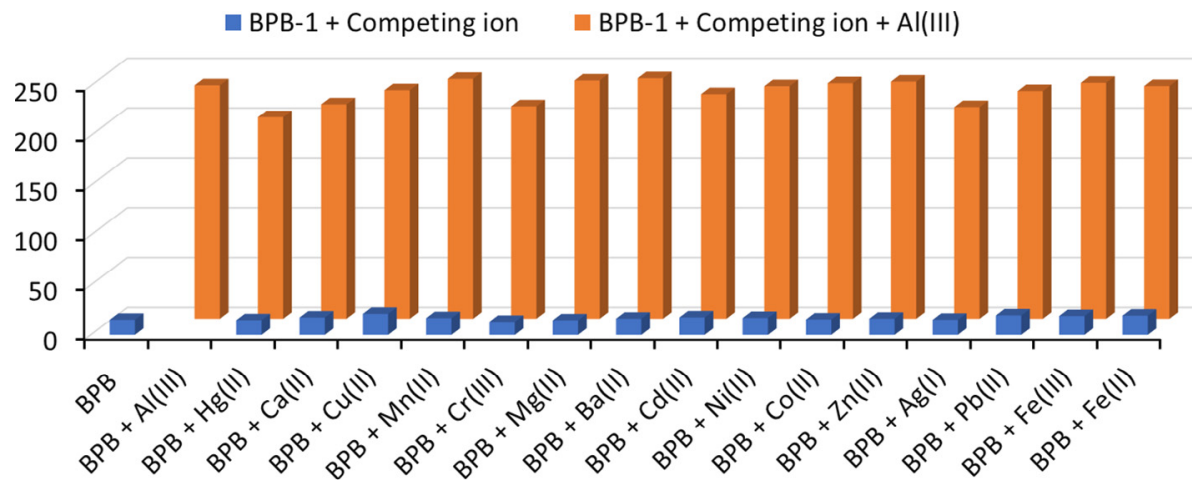

Fig. 3. Competitive fluorescence study of $\mathrm{BPB}\left(2 \mathrm{~mL}, 1 \times 10^{-5} \mathrm{M}\right.$, in $\left.\mathrm{CH}_{3} \mathrm{OH}\right)$ upon the addition of $\mathrm{Al}(\mathrm{III})\left(60 \mu \mathrm{L}, 1 \times 10^{-3} \mathrm{M}\right.$, in $\left.\mathrm{H}_{2} \mathrm{O}\right)$ and other interfering metal ions $\left(60 \mu \mathrm{L}, 1 \times 10^{-3} \mathrm{M}\right.$, in $\left.\mathrm{H}_{2} \mathrm{O}\right)$.

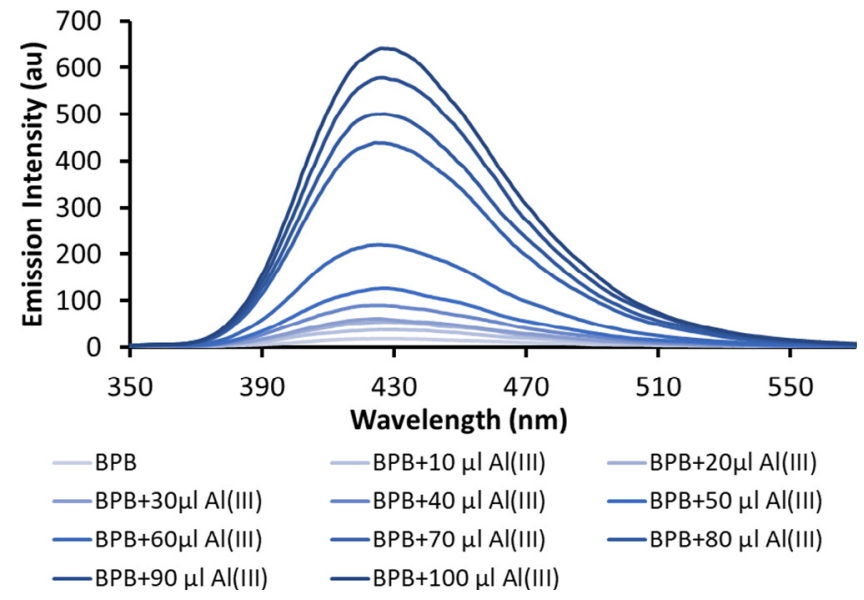

Fig. 4. Fluorescence spectral changes of $\mathrm{BPB}\left(2 \mathrm{~mL}, 1 \times 10^{-5} \mathrm{M}\right.$, in $\left.\mathrm{CH}_{3} \mathrm{OH}\right)$ upon the incremental addition of $\mathrm{Al}(\mathrm{III})\left(0-100 \mu \mathrm{L}, 1 \times 10^{-3} \mathrm{M}\right.$, in $\left.\mathrm{H}_{2} \mathrm{O}\right)$.

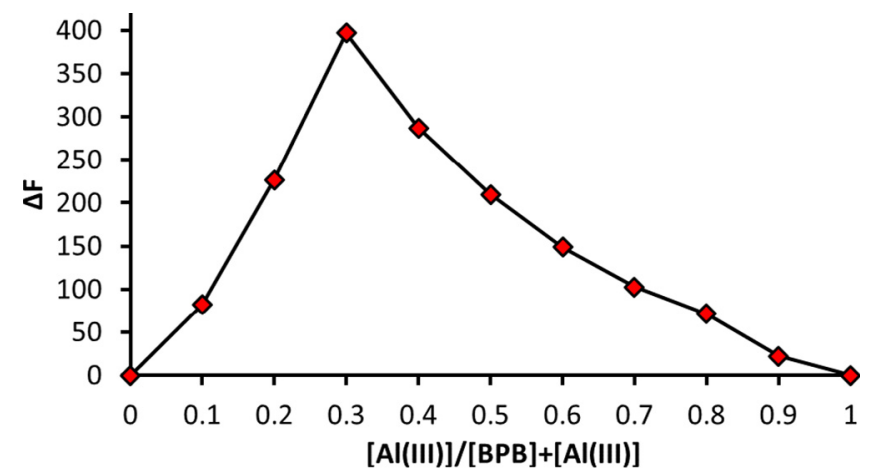

Fig. 5. Job,s plot for determining 2:1 binding stoichiometry of BPB $\left(1 \times 10^{-5} \mathrm{M}\right.$, in $\left.\mathrm{CH}_{3} \mathrm{OH}\right)$ and $\mathrm{Al}(\mathrm{III})$ ions $\left(1 \times 10^{-5} \mathrm{M}\right.$, in $\left.\mathrm{H}_{2} \mathrm{O}\right)$.

where the receptor is expected to provide three donor sites, i.e., phenolate- $\mathrm{O}$, imine- $\mathrm{N}$ and thiol-S. Further, the formation of a complex in 2:1 binding ratio was confirmed by recording the LC-MS spectra of BPB in the presence of $\mathrm{Al}(\mathrm{III})$ in $\mathrm{MeOH}$ (Fig. S4). The MS spectra showed a peak at $\mathrm{m} / \mathrm{z}=805.2$ matching to the complex [(2BPB$\left.2 \mathrm{H})+\mathrm{Al}^{3+}+\left(\mathrm{ClO}_{4}{ }^{-}\right)+\mathrm{Na}\right]^{+}$(Fig. S8).

The formation of complex species between $\mathrm{BPB}$ and $\mathrm{Al}(\mathrm{III})$ was complemented by performing ${ }^{1} \mathrm{H}$ NMR titration experiment (Fig. S9). The ${ }^{1} \mathrm{H}$ NMR spectra of $\mathrm{BPB}$ were recorded after adding different equivalents $(0.5,1$ and 2$)$ of $\mathrm{Al}(\mathrm{III})$ in DMSO- $d_{6}$. The titration experiment revealed that the peak at $12.20 \mathrm{ppm}$ corresponding to the phenolic-OH proton gets disappeared with the successive addition of $\mathrm{Al}(\mathrm{III})$ ions to the solution of BPB. Also, the imine proton peak of BPB at
$8.94 \mathrm{ppm}$ was shifted slightly towards upfield region. These observations confirm the participation of the donor atoms phenolate-O, imine$\mathrm{N}$ and thiol-S of BPB in complex formation with Al(III). Based on the experimental evidences, the 3D structure of the receptor BPB and its complex with $\mathrm{Al}(\mathrm{III})$ was calculated by applying the semi-empirical PM6 method at the gas phase [50,51]. The record BPB is planar in structure and undergoes some apparent conformational adjustment to form pseudo-octahedral complex with $\mathrm{Al}(\mathrm{III})$ (Fig. 6).

\subsection{Live cells imaging study of $B P B$}

The fluorescent 'turn-on' response from the receptor BPB upon addition of $\mathrm{Al}(\mathrm{III})$ prompted us to examine its ability to detect intracellular $\mathrm{Al}(\mathrm{III})$ concentration both qualitatively and quantitatively in A549 cell lines. The A549 cells were incubated with DMEM supplemented with $10 \%$ (v/v) fetal bovine serum (FBS, Gibco, USA) at $37{ }^{\circ} \mathrm{C}$ under a humidified atmosphere containing $5 \% \mathrm{CO}_{2}$. The A549 cells were planted on petri-dishes $(\Phi=20 \mathrm{~mm})$ and allowed to adhere for $24 \mathrm{hrs}$ before the treatments. After being incubated with BPB $(10 \mu \mathrm{M})$ in DMEM for $10 \mathrm{~min}$, the cells were imaged by a confocal fluorescence microscope. The results show very weak emission from the cells treated with the BPB alone (Fig. 7a). Subsequently, the cells containing BPB were treated with different concentrations of $\mathrm{Al}(\mathrm{III})$, i.e. $20 \mu \mathrm{M}, 30 \mu \mathrm{M}$ and $40 \mu \mathrm{M}$ of $\mathrm{Al}(\mathrm{III})$ and incubated for $30 \mathrm{~min}$ (Fig. $7 \mathrm{~b}-\mathrm{d}$ ). There is a significant intracellular fluorescence increase compared with the control cells revealed the good cell membrane permeability of the receptor BPB and also its ability to detect intracellular Al(III) ions. Further, the confocal fluorescence images became gradually brighter as the concentration of $\mathrm{Al}(\mathrm{III})$ increased from $20 \mu \mathrm{M}$ to $40 \mu \mathrm{M}$, which indicate the potential of BPB for quantitative monitoring of intracellular $\mathrm{Al}(\mathrm{III})$ concentrations.

\section{Conclusions}

In conclusion, a new fluorescent turn-on chemosensor was added into the library of $\mathrm{Al}(\mathrm{III})$ selective chemosensors. This easy-to-prepare tridentate Schiff base receptor BPB detects $\mathrm{Al}(\mathrm{III})$ in the aqueous methanolic medium by giving significant fluorescent enhancement at $430 \mathrm{~nm}$ due to the CHEF mechanism. The receptor BPB and $\mathrm{Al}(\mathrm{III})$ formed complex species in 2:1 binding stoichiometry. The limit of detection of receptor $\mathrm{BPB}$ for $\mathrm{Al}(\mathrm{III})$ is much better than the permissible limit of $\mathrm{Al}(\mathrm{III})$ concentration in drinking water. More importantly, the receptor BPB showed good cell permeability and detects intracellular Al (III) concentration both qualitatively and quantitatively in living A549 cells.

\section{Author's contribution}

Nilesh Kshirsagar, Prashant Patil, Jitendra Nandre and Pathan 

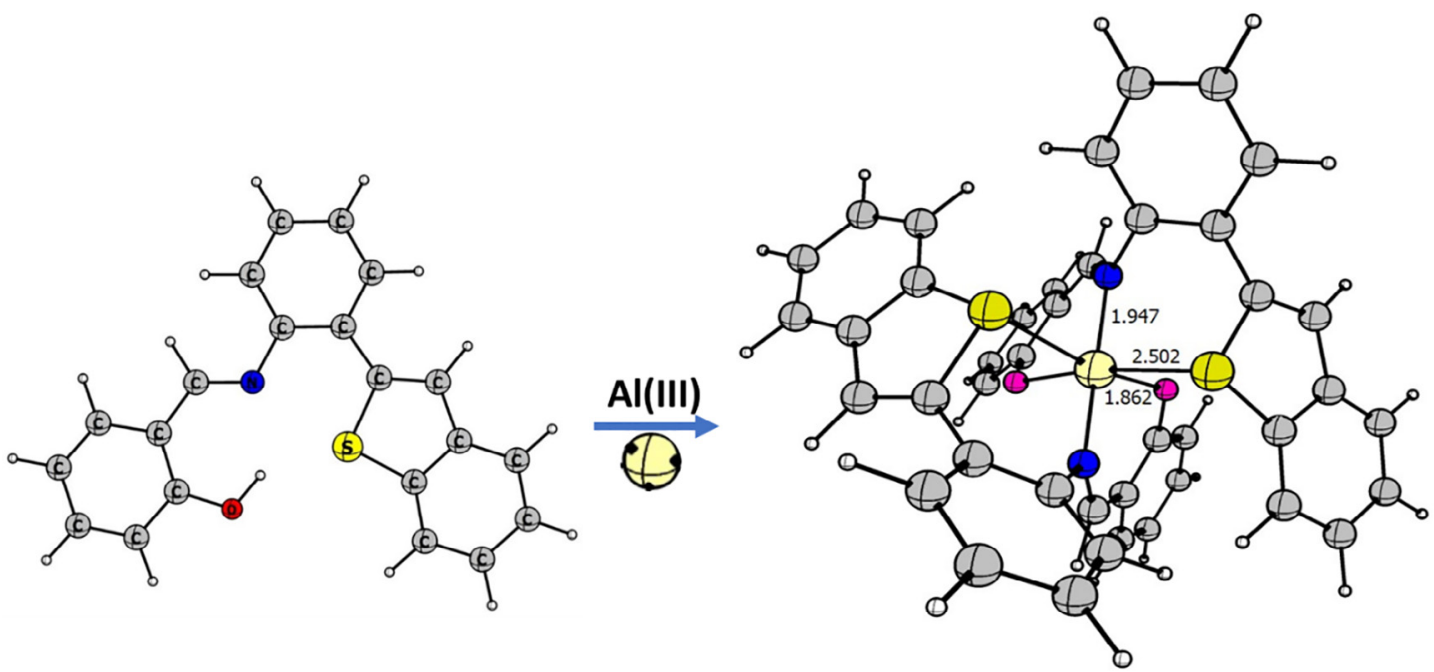

Fig. 6. The computed structure of receptor BPB and its complex with Al(III) by applying the semi-empirical PM6 method.

Sultan: Synthesized the receptor, performed the sensing studies, interpretation of data and drafting of manuscript.

Suman Sehlangia and Chullikkattil P. Pradeep: Recorded the spectra of NMR and Mass

Yue Wang and Lingxin Chen: performed the live cells imaging experiments

Ratnamala Sonawane: Drafting of the manuscript.

Suban K. Sahoo: Conception and design of study, drafting and editing of the manuscript.

\section{Declaration of Competing Interest}

The authors declare that they have no known competing financial interests or personal relationships that could have appeared to influence the work reported in this paper. (a)

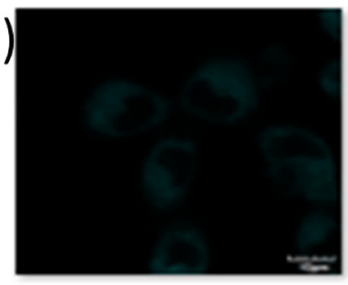

(b)

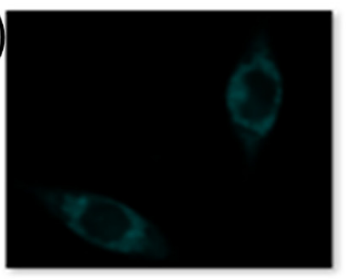

(c)

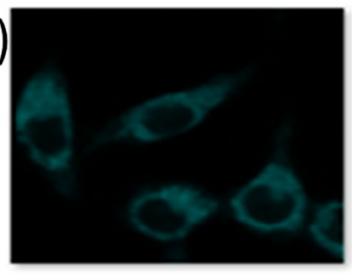

(d)

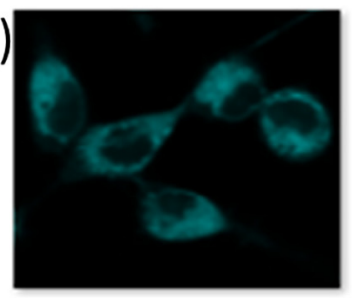

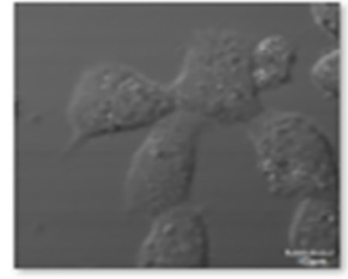
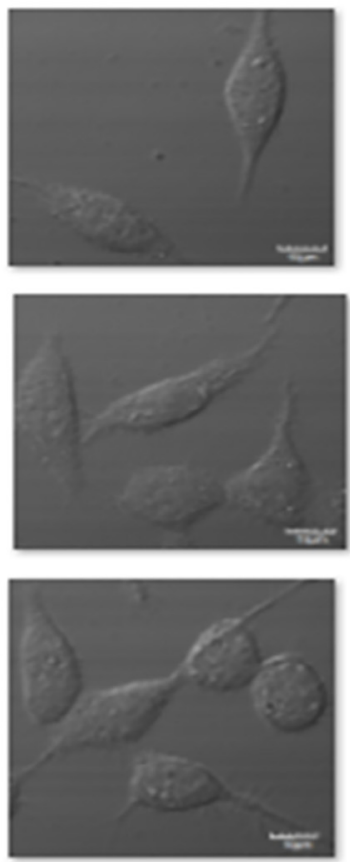
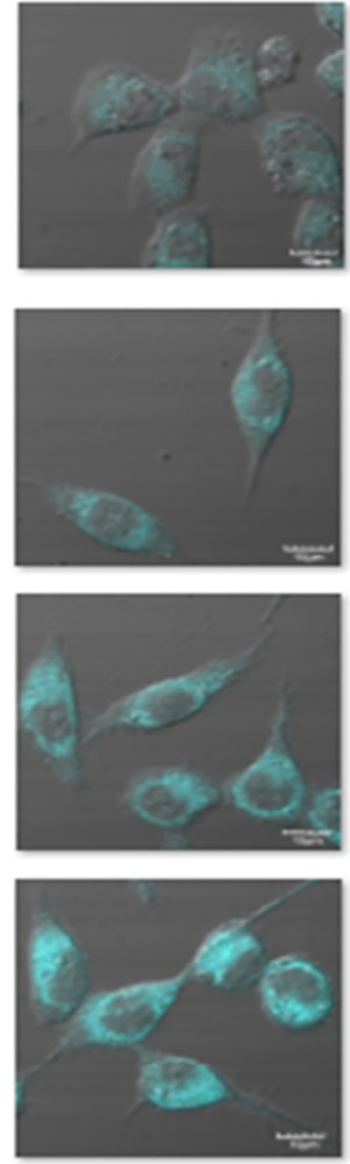

Fig. 7. Fluorescence confocal microscopic images of living A549 cells (left: fluorescence imaging; middle: bright field; right: merged images of fluorescence imaging and bright field): (a) cells loaded with $10 \mu \mathrm{M}$ of BPB, and cells loaded with both $10 \mu \mathrm{M}$ of BPB with Al(III) $20 \mu \mathrm{M}$ (b), $30 \mu \mathrm{M}$ (c) and $40 \mu \mathrm{M}$ (d). 


\section{Acknowledgements}

The authors are grateful for the financial and other research support from the Department of Chemistry, Institute of Science, Mumbai (India); Key Laboratory of Coastal Zone Environmental Processes and Ecological Remediation, Yantai Institute of Coastal Zone Research, Chinese Academy of Sciences, Yantai , China; IIT Mandi (Hmachal Pradesh); SVNIT, Surat (Gujrat); B.N. University, Udaipur (Rajasthan).

\section{Appendix A. Supplementary data}

Supplementary data to this article can be found online at https:// doi.org/10.1016/j.ica.2020.119805.

\section{References}

[1] M. Dong, Y.M. Dong, T.H. Ma, Y.W. Wang, Y. Peng, A highly selective fluorescence enhanced chemosensor for $\mathrm{Al} 3+$ in aqueous solution based on a hybrid ligand from BINOL scaffold and $\beta$-amino alcohol, Inorg. Chim. Acta 381 (2012) 137-142.

[2] S.L. Gui, Y.Y. Huang, F. Hu, Y.L. Jin, G.X. Zhang, L.S. Yan, D.Q. Zhang, R. Zhao, Fluorescence turn-on chemosensor for highly selective and sensitive detection and bioimaging of $\mathrm{Al} 3+$ in living cells based on ion-induced aggregation, Anal. Chem. 87 (2015) 1470-1474.

[3] S.K. Shoora, A.K. Jain, V.K. Gupta, A simple Schiff base based novel optical probe for aluminium(III) ions, Sens. Actuat. B Chem. 25 (2015) 86-104.

[4] T.Y. Han, X. Feng, B. Tong, J.B. Shi, L. Chen, J.G. Zhi, Y.P. Dong, A novel "turn-on" fluorescent chemosensor for the selective detection of $\mathrm{Al} 3+$ based on aggregation induced emission, Chem. Commun. 48 (2012) 416-418.

[5] S. Kim, J.Y. Noh, K.Y. Kim, J.H. Kim, H.K. Kang, S.W. Nam, S.H. Kim, S. Park, C. Kim, J. Kim, Salicylimine-based fluorescent chemosensor for aluminum ions and application to bioimaging, Inorg. Chem. 51 (2012) 3597-3602.

[6] H.T. Xie, Y.L. Wu, J. Huang, A ratiometric fluorescent probe for aluminum ions based-on monomer/excimer conversion and its applications to real samples, Talanta 151 (2016) 8-13.

[7] D.L. Godbold, E. Fritz, A. Hüttermann, Aluminum toxicity and forest decline, Proc. Natl. Acad. Sci. U.S.A 85 (1988) 3888-3892.

[8] E. Delhaize, P.R. Ryan, Aluminum toxicity and tolerance in plants, Plant Physiol 107 (1995) 315-321.

[9] E. House, M. Esiri, G. Forster, P.G. Ince, C. Exley, Aluminium, iron and copper in human brain tissues donated to the medical research council's cognitive function and ageing study, Metallomics 4 (2012) 56-65.

[10] A. Mirza, A. King, C. Troakes, C. Exley, Aluminium in brain tissue in familial Alzheimer's disease, J. Trace Elements Med. Biol. 40 (2017) 30-36.

[11] D. Perl, A. Brody, Alzheimer's disease: X-ray spectrometric evidence of aluminum accumulation in neurofibrillary tangle-bearing neurons, Science 208 (1980) 297-299.

[12] A. Becaria, A. Campbell, S.C. Bondy, Aluminum as a toxicant, Toxicol. Ind. Health 18 (2002) 309-320.

[13] A.M. Pierides, W.G. Edwards Jr, U.X. Cullum Jr, J.T. McCall, H.A. Ellis, Hemodialysis encephalopathy with osteomalacic fractures and muscle weakness, Kid. Int. 18 (1980) 115-124.

[14] B. Valeur, I. Leray, Design principles of fluorescent molecular sensors for cation recognition, Coord. Chem. Rev. 205 (2000) 3-40.

[15] T. Guray, Ü.D. Uysal, T. Gedikbey, A.A. Huseyinli, 2,2',3,4-Tetrahydroxy-3'-sulpho$5^{\prime}$-nitroazobenzene for spectrophotometric determination of aluminium in pharmaceutical suspensions and granite, Anal. Chim. Acta 545 (2005) 107-112.

[16] I. Narin, M. Tuzen, M. Soylak, Aluminium determination in environmental samples by graphite furnace atomic absorption spectrometry after solid phase extraction on Amberlite XAD-1180/pyrocatechol violet chelating resin, Talanta 63 (2004) 411-418.

[17] H. Wang, Z. Yu, Z. Wang, H. Hao, Y. Chen, P. Wan, Preparation of a preplated bismuth film on Pt electrode and its application for determination of trace aluminum(III) by adsorptive stripping voltammetry, Electroanal 23 (2011) 1095-1099.

[18] X. Xie, Y. Qin, A dual functional near infrared fluorescent probe based on the bodipy fluorophores for selective detection of copper and aluminum ions, Sens. Actuat. B 156 (2011) 213-217.

[19] P. Norouzi, V.K. Gupta, B. Larijani, S. Rasoolipour, F. Faridbod, M.R. Ganjali, Coulometric differential FFT admittance voltammetry determination of Amlodipine in pharmaceutical formulation by nano-composite electrode, Talanta 131 (2015) 577-584.

[20] H. Lian, Y. Kang, S. Bi, Y. Arkin, D. Shao, D. Li, Y. Chen, L. Dai, N. Gan, L. Tian, Direct determination of trace aluminum with quercetin by reversed-phase high performance liquid chromatography, Talanta 62 (2004) 43-50.

[21] I. Ali, V.K. Gupta, T.A. Khan, M. Asim, Removal of arsenate from aqueous solution by electro-coagulation method using Al-Fe electrodes, Int. J. Electrochem. Sci. 7 (2012) 1898-1907.

[22] Y.-W. Wang, M.-X. Yu, Y.-H. Yu, Z.-P. Bai, Z. Shen, F.-Y. Li, X.-Z. You, A colorimetric and fluorescent turn-on chemosensor for $\mathrm{Al} 3+$ and its application in bioimaging, Tetrahedron Lett 50 (2009) 6169-6172.

[23] R. Manjunath, E. Hrishikesan, P. Kannan, A selective colorimetric and fluorescent sensor for $\mathrm{Al} 3+$ ion and its application to cellular imaging, Spectrochim. Acta Part A 140 (2015) 509-515.

[24] L.Y. Qin, L.J. Hou, J. Feng, J.B. Chao, Y. Wang, W.J. Jin, A reversible turn-on colorimetric and fluorescent sensor for $\mathrm{Al} 3+$ in fully aqueous media and its living cell imaging, Syn. Metals 221 (2016) 206-213.

[25] P. Ravichandiran, A. Boguszewska-Czubara, M. Masłyk, A.P. Bella, P.M. Johnson, S.A. Subramaniyan, K.S. Shim, D.J. Yoo, A phenoxazine-based fluorescent chemosensor for dual channel detection of $\mathrm{Cd}^{2+}$ and $\mathrm{CN}^{-}$ions and its application to bioimaging in live cells and zebrafish, Dyes Pigments 172 (2020) 107828.

[26] C. Liang, W. Bu, C. Li, G. Men, M. Deng, Y. Jiangyao, H. Sunb, S. Jiang, A highly selective fluorescent sensor for $\mathrm{Al} 3+$ and the use of the resulting complex as a secondary sensor for PPi in aqueous media: its applicability in live cell imaging, Dalton Trans. 44 (2015) 11352-11359.

[27] P. Ravichandiran, S.A. Subramaniyan, A.P. Bella, P.M. Johnson, A.R. Kim, K.S. Shim, D.J. Yoo, Simple fluorescence turn-on chemosensor for selective detection of $\mathrm{Ba}^{2+}$ ion and its live cell imaging, Anal. Chem. 91 (2019) 10095-10101.

[28] S.K. Sahoo, D. Sharma, R.K. Bera, G. Crisponi, J.F. Callan, Iron (III) selective molecular and supramolecular fluorescent probes, Chem. Soc. Rev. 41 (2012) 7195-7227.

[29] G.R.C. Hamilton, S.K. Sahoo, S. Kamila, N. Singh, N. Kaur, B.W. Hyland, J.F. Callan, Optical probes for the detection of protons, and alkali and alkaline earth metal cations, Chem. Soc. Rev. 44 (2015) 4415-4432.

[30] P. Ravichandiran, A. Boguszewska-Czubara, M. Masłyk, A.P. Bella, S.A. Subramaniyan, P.M. Johnson, K.S. Shim, H.G. Kim, D.J. Yoo, Naphthoquinonebased colorimetric and fluorometric dual-channel chemosensor for the detection of $\mathrm{Fe}^{2+}$ ion and its application in bio-imaging of live cells and zebrafish, ACS Sustain. Chem. Eng. 7 (2019) 17210-17219.

[31] A. Kuwar, R. Patil, A. Singh, S.K. Sahoo, J. Marek, N. Singh, A two-in-one dual channel chemosensor for $\mathrm{Fe} 3+$ and $\mathrm{Cu} 2+$ with nanomolar detection mimicking the IMPLICATION logic gate, J. Mater. Chem. C 3 (2015) 453-460.

[32] S.K. Sahoo, D. Sharma, A. Moirangthem, A. Kuba, R. Thomas, R. Kumar, A. Kuwar, H.-J. Choi, Anupam Basu, Pyridoxal derived chemosensor for chromogenic sensing of $\mathrm{Cu} 2+$ and fluorogenic sensing of $\mathrm{Fe} 3+$ in semi-aqueous medium, J. Luminesc. 172 (2016) 297-303.

[33] Y. Upadhyay, P. Paira, S.K. Ashok Kumar, H.-J. Choi, R. Kumar, S.K. Sahoo, Vitamin B6 cofactor conjugated rhodamine $6 \mathrm{G}$ derivative: Fluorescent turn-on sensing of Al (III) and $\mathrm{Cr}$ (III) with bioimaging application in live HeLa cells, Inorg. Chim. Acta 489 (2019) 198-203.

[34] Y. Upadhyay, T. Anand, L.T. Babu, P. Paira, G. Crisponi, R. Kumar, S.K. Sahoo, Three-in-one type fluorescent sensor based on a pyrene pyridoxal cascade for the selective detection of Zn(II), hydrogen phosphate and cysteine, Dalton Trans. 47 (2018) 742-749.

[35] A. Gogoi, S. Samanta, G. Das, A benzothiazole containing CHEF based fluorescence turn-on sensor for $\mathrm{Zn} 2+$ and $\mathrm{Cd} 2+$ and subsequent sensing of $\mathrm{H}_{2} \mathrm{PO}_{4}^{-}$and $\mathrm{P}_{4} \mathrm{O}_{7}{ }^{4}$ in physiological pH, Sens. Actuat. B Chem. 202 (2014) 788-794.

[36] J. Wu, W. Liu, J. Ge, H. Zhang, P. Wang, New sensing mechanisms for design of fluorescent chemosensors emerging in recent years, Chem. Soc. Rev. 40 (2011) 3483-3495.

[37] A. Thangaraj, V. Bhardwaj, S.K. Sahoo, A multi-analyte selective dansyl derivative for the fluorescence detection of $\mathrm{Cu}(\mathrm{ii})$ and cysteine, Photochem. Photobiol. Sci. 18 (2019) 1533-1539.

[38] Z.P. Liu, W.J. He, Z.J. Guo, Metal coordination in photoluminescent sensing, Chem. Soc. Rev. 42 (2013) 1568-1600.

[39] K. Tiwari, M. Mishra, V.P. Singh, A highly sensitive and selective fluorescent sensor for $\mathrm{Al} 3+$ ions based on thiophene-2-carboxylic acid hydrazide Schiff base, RSC Adv. 3 (2013) 12124-12132.

[40] S. Sharma, M.S. Hundal, A. Walia, V. Vanitab, G. Hundal, Nanomolar fluorogenic detection of Al(III) by a series of Schiff bases in an aqueous system and their application in cell imaging, Org. Biomol. Chem. 12 (2014) 4445-4453.

[41] J.C. Qin, Z.Y. Yang, L. Fan, X.Y. Cheng, T.R. Li, B.D. Wang, Design and synthesis of a chemosensor for the detection of Al3 + based on ESIPT, Anal. Methods 6 (2014) 7343-7348.

[42] T. Anand, S.K. Ashok Kumar, S.K. Sahoo, A new Al3 + selective fluorescent turn-on sensor based on hydrazide-naphthalic anhydride conjugate and its application in live cells imaging, Spectrochim. Acta A 204 (2018) 105-112.

[43] W.H. Ding, W. Cao, X.J. Zheng, W.J. Ding, J.P. Qiao, L.P. Jin, A tetrazole-based fluorescence "turn-on" sensor for $\mathrm{Al}(\mathrm{III})$ and $\mathrm{Zn}(\mathrm{II})$ ions and its application in bioimaging, Dalton Trans. 43 (2014) 6429-6435.

[44] W. Cao, X.J. Zheng, J.P. Sun, W.T. Wong, D.C. Fang, J.X. Zhang, L.P. Jin, A highly selective chemosensor for $\mathrm{Al}(\mathrm{III})$ and $\mathrm{Zn}$ (II) and its coordination with metal ions, Inorg. Chem. 53 (2014) 3012-3021.

[45] E. David, S. Pellet-Rostaing, M. Lemaire, Heck-like coupling and pictet-spengler reaction for the synthesis of benzothieno[3,2-c] quinolones, Tetrahedron 63 (2007) 8999-9006.

[46] K. Takamatsu, K. Hirano, Synthesis of carbazoles by copper-catalysed C-H/N-H coupling, Org. Lett. 16 (2014) 2892-2895.

[47] J. Wang, Y. Pang, A simple sensitive ESIPT on-off fluorescent sensor for selective detection of $\mathrm{Al}^{3+}$ in water, RSC Adv, 4 (2014) 5845-5848.

[48] P. Torawane, K. Tayade, S. Bothra, S.K. Sahoo, N. Singh, A. Borse, A. Kuwar, A highly selective and sensitive fluorescent 'turn-on' chemosensor for Al3 + based on $\mathrm{C}=\mathrm{N}$ isomerisation mechanism with nanomolar detection, Sens. Actuat. B Chem. 222 (2016) 562-566.

[49] I.H. Hwang, Y.W. Choi, K.B. Kim, G.J. Park, J.J. Lee, L.T. Nguyen, I. Noh, C. Kim, A highly selective and sensitive fluorescent turn-on $\mathrm{Al}^{3+}$ chemosensor in aqueous media and living cells: experimental and theoretical studies, New J. Chem. 40 (2016) 171-178.

[50] M.J. Frisch Gaussian 09W, Revision A.1, Gaussian Incorp 2009 Wallingford, CT.

[51] J. Rezac, J. Fanfrlık, D. Salahub, P. Hobza, Semiempirical quantum chemical PM6 method augmented by dispersion and H-bonding correction terms reliably describes various types of noncovalent complexes, J. Chem. Theory Comput. 5 (2009) 1749-1760. 